DOI https://doi.org/10.18551/rjoas.2018-11.44

\title{
FRESH FISH MARKETING ANALYSIS OF SMALL-SCALE FISHERIES IN BELU, EAST NUSA TENGGARA OF INDONESIA
}

\author{
Kiuk Johanis W.* \\ Faculty of Economics, Artha Wacana Christian University, Kupang, Indonesia \\ Rehatta Beatrix M. \\ Faculty of Fisheries and Marine Sciences, Artha Wacana Christian University, \\ Kupang, Indonesia \\ Ninef Jotham S.R. \\ Faculty of Marine and Fisheries, University of Nusa Cendana, Kupang, Indonesia \\ *E-mail: jhnkiuk@ukaw.ac.id
}

\begin{abstract}
Small-scale fisheries play main role in fish capture and fulfillment of fish demand for local people primarily in Belu. In the activities of fisheries resources utilization, marketing seems to be an important part in order to distribute fish catch to consumers. The main problems majorily come from fish perishability (highly susceptible to deterioration and quality degradation), in which the production centers are distributed to many locations and far from retail markets. Marketing system should be established properly, enabling to effectively distribute fishery products to consumers while maintaining their quality. This research was conducted in fish production centers of Belu, specifically in some villages, i.e. Silawan, Kenebibi, Jenilu and Dualaus, as well as in fish market center in Atambua. The analysis of fresh fish marketing system in small-scale fisheries in Belu focused mainly on marketing channels and marketing functions in each marketing institution. As a result, marketing channel for fresh fish in Belu consisted of six types that involved six marketing institutions. The marketing factors included selling, purchasing, sortation, storage, transportation, risk, cost, and market information. All marketing institutions performed following functions: selling, risk, cost, and market information, while retailers performed entire marketing functions. However, other agents performed some marketing functions.
\end{abstract}

\section{KEY WORDS}

Marketing, small-scale fisheries, Belu, public service.

Marketing is an essential in fishery activities; fish catch is commercially valuable when it is purchased (Hanafiah and Saefuddin 2006). Marketing activities involved positioning and market control (especially buyer) for fish catches by fishermen, cooperation, company, and community. In short, the activities could provide commercial income for fishermen, enabling to produce significant positive impact to them, while unsold fish could adversely affect their income. Marketing refers to the activities in order to ensure that fresh fish from marine are transported to the next destination in micro level, which is highly essential for fishermen, cooperation, company, and community. In micro level, fish marketing included promotion for fish consumption (for instance by a national campaign for fish consumption by a particular organization) and specific promotion (for instance by advertisements for targeted countries). In this case, the efforts for enhancement of marketing and distribution significantly contributed to the economy development in a region. The fish distribution mechanism is also crucial, where marketing system is accomplished when the fish reach buyers. This is noteworthy that in fact, people in developing countries, even reaching $50 \%$ of total population, cannot eat fish due to a simple main cause, i.e. unavailability. In some countries, the fish consumption per capita was low which may be ascribed to high cost, but in other parts of the world, fish is not considered as traditional food, resulting in a low demand. 
In this study, analysis of fresh fish marketing system in Belu District was performed using functional and institutional approach. Institutional approach is based on analysis of marketing channels, while functional approach is based on analysis of marketing functions performed by all involved institutions in each marketing agent.

\section{METHODS OF RESEARCH}

This current work was conducted in fish production and marketing centers in some villages of Belu District, i.e. Silawan, Kenebibi, Jenilu and Dualaus, and central market in Atambua City. Data were collected using survey and observation. Survey was performed using semi-structured interview. Respondents were selected according to purposive sampling, intentionally selecting them based on roles of the respondents in fish marketing chain, including fishermen, retailer, assembly agent, wholesaler, and consumer. Observation was conducted using non-participative method towards fish marketing activities. Parameters of the research included 1) identification of marketing institutions, 2) analysis of marketing channels, and 3) analysis of marketing functions performed by each marketing institution. Data were then analyzed using descriptive-analytic approach.

\section{RESULTS AND DISCUSSION}

Small-scale fisheries performance. Fishing vessels in Belu are categorized into 3 types, i.e. motorized boats, outboard motorized boat, and non-motorized boat, as presented in Table 1.

Table 1 - Number of fishing boat by its type in Belu, 2012-2014

\begin{tabular}{llllll}
\hline \multirow{2}{*}{ No } & Type of boat & \multicolumn{3}{l}{ Number (Unit) } & Increment (\%) \\
\cline { 3 - 5 } & Non-motorized boat & 6012 & 2013 & 2014 & \\
\hline 1. & a. Jukung (wooden boat) & 542 & 559 & 545 & 7.14 \\
& b. Perahu Papan (wooden plank-built boat) & 60 & 86 & 86 & 4.14 \\
& $\bullet \quad$ Small & 27 & 44 & 44 & 62.96 \\
& $\bullet \quad$ Medium & 18 & 27 & 27 & 50.00 \\
& $\bullet \quad$ Large & 15 & 15 & 15 & 0 \\
2. & Outboard motorized boat & 295 & 318 & 325 & 10.17 \\
3. & Motorized boat & 48 & 53 & 53 & 10.42 \\
\hline Total & & 945 & 1016 & 1023 & 8.25 \\
\hline
\end{tabular}

Source: DKP of Belu (2015).

According to a number of fishing vessels in 2014 , we could mention that non-motorized boat seemed to be dominant $(63.05 \%)$, being significantly higher than outboard motorized boat $(31.77 \%)$ and motorized boat $(5.18 \%)$, as reported by DKP of Belu (2015). This suggests that capture fisheries in Belu are a small-scale fishery, which commonly operates in onshore or along the coast from their home with a limited operational range.

Fishing gears in Belu may vary, depending on the need of fishermen. In this case, we reported 9 types of fishing gear, i.e seine net, purse seine, gill net, trammel net, lift net, pole and line, cash net, bubu (trap), and others, as presented in Table 2.

Table 2 - Type and percentage of fishing gear in Belu

\begin{tabular}{|c|c|c|c|c|c|}
\hline \multirow{2}{*}{ No } & \multirow{2}{*}{ Type of fishing gear } & \multicolumn{2}{|c|}{ Number (Unit) } & \multicolumn{2}{|c|}{ Percentage (\%) } \\
\hline & & 2013 & 2014 & 2013 & 2014 \\
\hline 1. & Seine net & 10 & 16 & 0.46 & 0.78 \\
\hline 2. & Purse seine & 6 & 0 & 0.27 & 0 \\
\hline 3. & Gill net & 999 & 833 & 45.78 & 40.67 \\
\hline 4. & Trammel net & 246 & 291 & 11.27 & 14.21 \\
\hline 5. & Lift net & 6 & 6 & 0.27 & 0.29 \\
\hline 6. & Pool and line & 528 & 515 & 24.20 & 25.15 \\
\hline 7. & Cash net & 186 & 186 & 8.52 & 9.08 \\
\hline 8. & Bubu (trap) & 151 & 151 & 6.92 & 7.37 \\
\hline 9. & Other & 50 & 50 & 2.29 & 2.44 \\
\hline Total & & 2182 & 2048 & 100 & 100 \\
\hline
\end{tabular}

Source: DKP of Belu (2015). 
As mentioned above, the dominant fishing gear in Belu was gill net, pool and line, trammel net, cash net, and bubu, accounting for $95 \%$ of the total fishing gear used in Belu. The characteristics of the common fishing tool in Belu sea are passive fishing gear which is used in shallow waters around sea grass area and coral reefs. This indicates that most fishermen in Belu are traditional fishers that operate in shallow waters using various simple fishing tools. The finding is also in line with limitation in number and capacity of vessels dominated by non-motorized boat and outboard motorized boat $(94.82 \%)$.

Capture fisheries commodities in Belu included 5 types of fish resources, i.e. small pelagic, large pelagic, demersal fish, mollusc, and crustacea (Figure 1). Based on DKP of Belu (2015), small pelagic showed the greatest contributor for capture fisheries in 2014, reaching $38.52 \%$, followed by large pelagic (31.43\%), demersal fish $(19.89 \%)$, crustaceae $(6.60 \%)$ and mollusc $(3.56 \%)$.

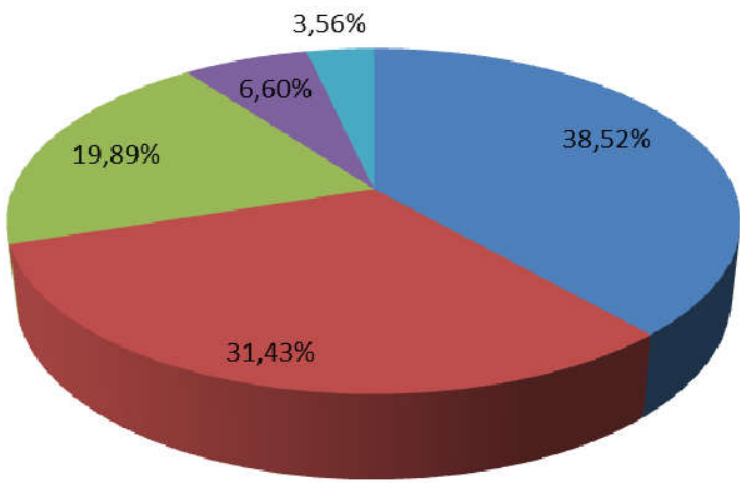

Small pelagic fish $\square$ Large pelagic fish Demersal fish $\square$ Crustaceae Mollusc

Figure 1 - Contributor of capture fisheries by group of fish resources in Belu

(Source: DKP of Belu 2015)

Fishery households (Rumah Tangga Perikanan, RTP) and fishermen in Belu were categorized into 3 groups based on their livelihood, i.e. full-time fishermen, part-time (major) fishermen, and part-time (minor) fishermen. Totally, their population reached 2925 people in 2014, consisting of 1266 (43.28\%) full-time fishermen, 247 (8.44\%) part-time (major) fishermen, and $1412(48.27 \%)$ part-time (minor) fishermen. The full-time fishermen from RTP were recorded at 378 RTP $(28.70 \%)$, while their number as major and minor part-time fishermen was 86 RTP (6.53\%) and 853 RTP (64.77\%), respectively (DKP of Belu, 2015).

Marketing channels. Fishery products are perishable, which means that they are highly susceptible to spoilage. In addition, their production centers are also not concentrated and far away from markets (Hanafiah and Saefuddin 2006). Furthermore, there is a need to establish marketing system allow providing a rapid distribution of fish to consumers without reducing the quality of fish. Hidayati (2000) reported that marketing institution services were strongly helpful in order to connect producers and consumers.

Marketing channels in small-scale fihseries located in Belu comprised of 7 marketing institutions, including:

1. Fishermen;

2. Retailers;

3. Assembly agents;

4. Wholesalers;

5. Non-native fishermen;

6. Consumers.

A marketing channel refers to channel actors as a sequence of institutions that carry out the transfer of goods from the producer to the end-costumer. In general, a product may have more than one marketing channel, either complex or simple pattern, mainly depending on the type of product. Marketing institutions capable of distributing product rapidly often 
possess a simpler channel. Activities on marketing channel are strategic efforts which are based on their capability to create assistance on producing economical value. The economical value itself can determine the price of product and service to individuals (Swastha 2002). In marketing channel, producers frequently involve middlemen or intermediaries, referred to an independent and distinct institution standing between producers and end-customers.

In this present work, the pattern of fresh fish marketing channel in small-scale fisheries in Belu is described as follows:

1. Fishermen - consumers;

2. Fishermen - retailers - consumers;

3. Fishermen - assembly agents - retailers - consumers;

4. Fishermen - assembly agents - consumers;

5. Fishermen - wholesalers;

6 . Fishermen - non-native fishermen.

The schematic description of marketing channel is depicted in Figure 2.

1

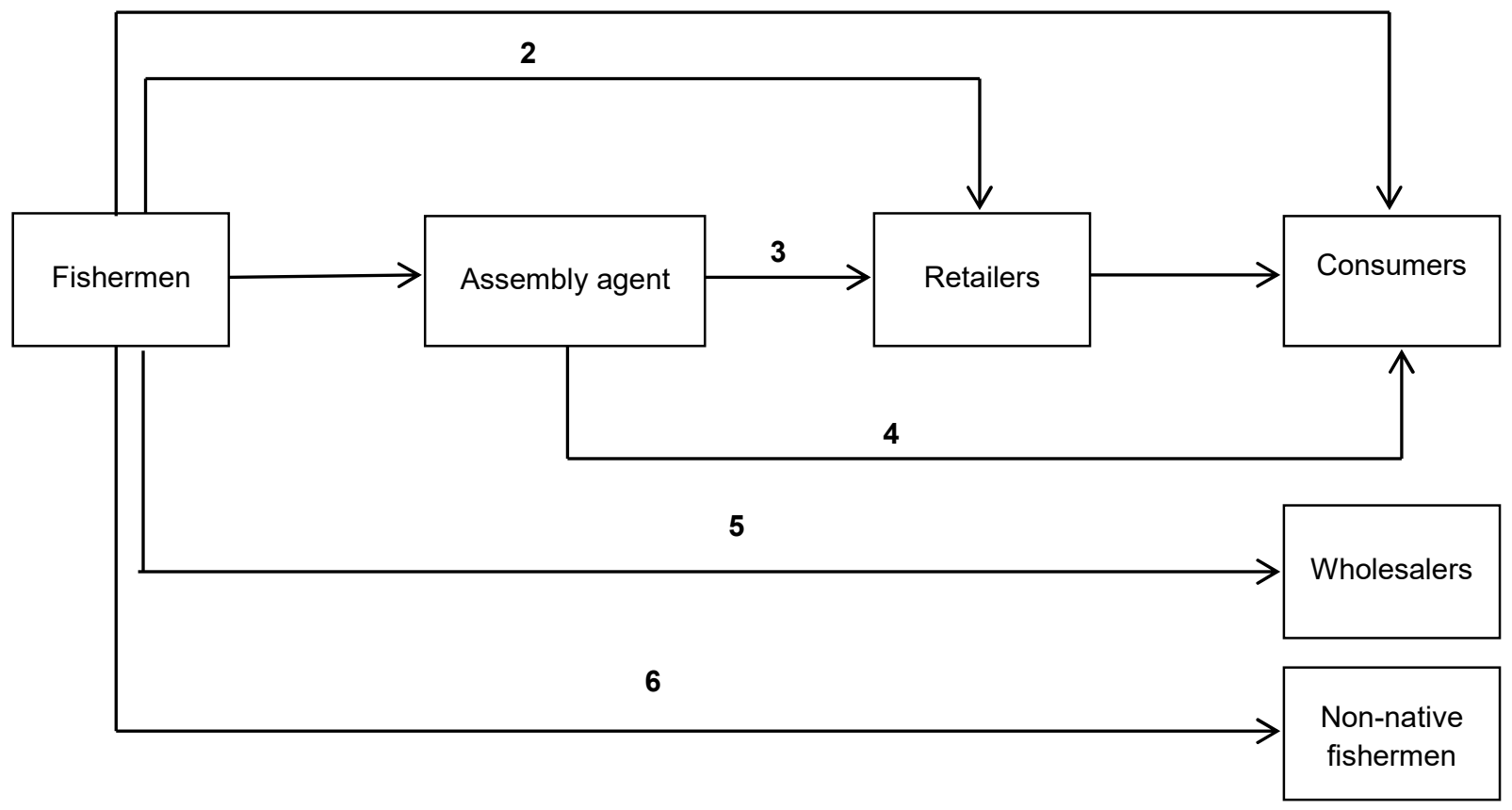

Figure 2 - Marketing channel of fresh fish in Belu

1. Fishermen - Consumers. This marketing channel occurs when consumers are close to the fishermen as procuders. In this case, consumers buy fish just after the fish are landed in port or coast. The consumers are also from fishery household. They purchase fish due to absence of their family in fishing activities.

2. Fishermen - Retailers - Consumers. In this channel, retailers closely live with fishermen, or even they are part of the fishermen's family (wife, children, sister). The fish are then brought to market in Atambua or sold along main road near their home. This marketing channel is often used by fishermen when the volume of fish catch is low. Through this strategy, fishermen can directly collect money from their selling. Retailers, that may be fishermen's wife, daughter, and sister, directly use the money to buy their main foods such as rice and frying oil, after selling fish.

3. Fishermen - Assembly agent - Retailers - Consumers. This channel seems to be one of the most popular pathways in Belu. This is used by many fishermen that capture fish using lampara net since the fishing gear allows to capture fish in a large volume. Fishermen and assembly agent have established an agreement to sell the fish for a long time. This allows the fishermen to keep earning money at a high supply of fish, since assembly agent purchase their fish. The assembly agent has a full control to the fish in market. From market, 
the fish are then distributed to retailers and sold to concumers. During low fishing season, where fish are rather scarce, the fishermen have to sell their capture to regular assembly agent, although they may have a better option to sell fish to other agents, enabling them to earn more money.

4. Fishermen - Assembly agents - Consumers. In this case, assembly agents also operate as retailers, depending on fish availability. In excessive fish supply, assembly agents serve to collect fish and sell it to retailers. In contrast, at a limited fish supply, they directly sell fish to consumers in market. The assembly agents can obtain a lot of profits through this marketing channel.

5. Fishermen - Wholesalers. This present channel often occurs for tuna, in which fishermen have already built cooperation with wholesalers that will buy their fish. The company (buyer) covers operational cost and in some cases, they also provide fishing vessels. The main market for tuna is in other regions such as Bali and export in either whole or loin form to Timor Leste. In 2016, total fishery products for other area and export to Timor Leste by wholesalers reached $135,388.8 \mathrm{~kg}$.

6. Fishermen - Non-native fishermen. The most cases for this channel are from fish capture using fish hook and lampara in around Fishing Aggregating Device (FAD). The fish catches are often sold to fishermen from Timor Leste and the transaction is conducted in sea, just before landing to the port. This is a common activity since they have established a collaborative understanding in capturing fish around FAD. When fishermen from Timor Leste are unable to catch fish in FAD, they will purchase fish from local fishermen and bring it to their country.

Marketing function. Marketing function performed by marketing institutions include 3 main aspects: exchange (selling and purchasing), physic (sortation, storage, transportation), and facility (risk, cost and market information). All marketing institution perform selling, risk, cost and market information function. Retailers are found to perform all marketing functions studied, while other institutions perform some functions, as presented in Table 3.

Table 3 - Marketing functions of small-scale fisheries by institutions in Belu

\begin{tabular}{|c|c|c|c|c|c|c|c|c|}
\hline \multirow{3}{*}{$\begin{array}{l}\text { Marketing institution } \\
\text { channels }\end{array}$} & \multicolumn{8}{|c|}{ Marketing function } \\
\hline & \multicolumn{2}{|c|}{ Exchange } & \multicolumn{3}{|l|}{ Physic } & \multicolumn{3}{|c|}{ Facility } \\
\hline & Selling & Purchaning & Transportation & Storage & Sortation & Risk & Cost & $\begin{array}{l}\text { Market } \\
\text { Information }\end{array}$ \\
\hline Channel 1: & & & & & & & & \\
\hline Fishermen & * & & & & * & * & * & \\
\hline Channel 2: & & & & & & & & \\
\hline Fishermen & * & & & & & * & * & * \\
\hline Retailer & * & * & * & * & * & * & * & * \\
\hline Channel 3 & & & & & & & & \\
\hline Fishermen & * & & & & & * & * & * \\
\hline Assembly agent & * & * & * & & & * & * & * \\
\hline Retailer & * & * & * & * & * & * & * & * \\
\hline Channel 4 & & & & & & & & \\
\hline Fishermen & * & & & & & * & * & * \\
\hline Assembly agent & * & * & * & * & * & * & * & * \\
\hline Channel 5: & & & & & & & & \\
\hline Fishermen & * & & & & * & * & * & \\
\hline Wholesaler & * & * & * & * & * & * & * & * \\
\hline Channel 6: & & & & & & & & \\
\hline Fishermen & * & & & & & & * & * \\
\hline Non-native fishermen & * & * & * & * & * & * & * & * \\
\hline
\end{tabular}

\section{CONCLUSION}

Marketing channels of fresh fish in small-scale fisheries in Belu covered 6 channels that involved 6 marketing institutions. The marketing functions performed by the studied institutions included selling, purchasing, sortation, storage, transportation, risk, cost, and 
market information. Retailers were observed to perform all marketing functions, while others performed some marketing functions.

\section{ACKNOWLEDGEMENTS}

Authors would like to express thank to General Directorate of Higher Education, Ministry of Research and Higher Education, for providing financial support under scheme of Applied Product Research (Penelitian Produk Terapan, PPT) year 2017 - 2018.

\section{REFERENCES}

1. Apituley, Y.M.N.T., D Bawole. 2017. Development of fresh fish marketing in Maluku. Occasional papers No. 58 (March 2017)

2. Baba, Md., I.D. Sanchi, T.A. Manga. 2015. Analysis of fresh fish marketing in Ngaski Local Government Area of Kebbi State, Nigeria. International Journal of Sustainable Agricultural Research. Vol. 2, No. 2. Pp 22-30

3. Butler JRA, R Gunn, HL Berry, GA Wagey, BD Hardesty, C Wilcox. 2013. A value chain analysis of ghost nets in the Arafura Sea: Identifying trans-boundary stakeholders, intervention points and livelihood trade-offs. Journal of Environmental Management 123 (2013) 14-25.

4. DKP [Dinas Kelautan dan Perikanan] Kabupaten Belu. 2015. Status Pengembangan Perikanan Tangkap dan Perikanan Budidaya di Kabupaten Belu.

5. DKP [Dinas Kelautan dan Perikanan] Provinsi Nusa Tenggara Timur. 2016. Statistik Perikanan Tangkap 2016. Dinas Kelautan dan Perikanan Provinsi Nusa Tenggara Timur. Kupang.

6. Fauzi, A. 2004. Ekonomi Sumberdaya Alam dan Lingkungan: Teori dan Aplikasi. PT. Gramedia Pustaka Utama, Jakarta.

7. Hanafiah AM, Saefuddin AM. 2006. Tataniaga Hasil Perikanan. Penerbit Universitas Indonesia. Jakarta.

8. Hidayati A. 2000. Analisis Kinerja Sistem Pemasaran dan Lembaga Penunjang Pemasaran Kaitannya Dengan Pengembangan Produksi Rumput Laut di Kabupaten Lombok Timur [Tesis]. Program Pascasarjana, Institut Pertanian Bogor. Bogor.

9. Kotler P, Amstrong G. 2004. Dasar-Dasar Pemasaran. Terjemahan Alex Sindoro dan Bambang Sarwiji, Edisi Sembilan, Jilid 1 dan 2. PT Indeks. Jakarta.

10. Luhur, ES, R. Yusuf. 2017. Analisis rantai nilai ikan cakalang di Kota Ambon, Maluku. Jurnal Sosek KP Vol. 12 No. 1. Juni 2017: 93-105

11. Nielsen M, P Andersen, L Ravensbeck, F Langesen, DM Kristofersson, H Ellefsen. 2017. Fisheries management and the value chain: The Northeast Atlantic pelagic fisheries case. Fisheries Research 186 (2017) 36-47.

12. Nikijuluw VPH. 2002. Rezim Pengelolaan Sumberdaya Perikanan. Kerjasama P3R dengan PT Pustaka Cidesindo. Jakarta.

13. Purwaningsih, R. 2015. Analisis Nilai Tambah Produk Perikanan Lemuru Pelabuhan Muncar Banyuwangi. Jurnal IImiah Teknik Industri, 14(1): 13-23.

14. Rosales RM, R Pomeroy, IJ Calabio, M Batong, K Cedo, N Escara, V Facunla, A Gulayan, M Narvadez, M Sarahadil, MA Sobrevega. 2017. Value chain analysis and small-scale fisheries management. Marine Policy 83 (2017) 11-21.

15. Swastha B. 2002. Azas-Azas Marketing. Edisi II. Penerbit Liberty. Yogyakarta.

16. Widodo J, Suadi. 2006. Pengelolaan Sumberdaya Perikanan Laut. Gadjah Mada University Press. Yogyakarta. 